\title{
Pituitary Macroadenoma with Apoplexy in an Adult: A Case Report
}

\author{
Fakhri Amin Nasution*, Brama Ihsan Sazli \\ Department of Internal Medicine, Faculty of Medicine, University of Sumatera Utara, Medan, North \\ Sumatera, Indonesia
}

\begin{abstract}
Background: Pituitary adenoma is the most benign tumor of hormone-producing cells in the anterior pituitary gland, ranging from $10 \%-15 \%$ of the entire intracranial mass. The prevalence of pituitary adenoma is still unknown. Epidemiological studies are still very limited and external factors such as the enforcement of diagnosis, disease distribution, and others resulting in limited epidemiological, postmortem, and radiological study data. Pituitary adenoma is often asymptomatic or asymptomatic and is not typical so the diagnosis is too late. Clinical manifestations of adenohipofisis: hypersecretion syndrome or hormonal deficiency; neurological manifestations due to the effects of an enlarged mass with imaging modalities. Case presentation: A 49-year-old man was referred to hospital with complaints of chronic headaches and blurred vision. Physical examination is generally within normal limits. Previous history of the disease or treatment is also not specific. MRI of the brain shows hyperintens lesions in the supracellular or sellar area. Hormone test findings also show hypocortisolism and hyperprolactinemia. Conclusion: Conservative treatment is carried out with a hormone deficiency subsite.
\end{abstract}

Keyword: Pituitary adenoma; hiperprolactinism; hypocortisolism

\begin{abstract}
Abstrak. Latar belakang: Adenoma hipofisis merupakan tumor jinak tersering dari sel penghasil hormon di kelenjar hipofisis anterior, berkisar 10\%-15\% dari seluruh massa intrakranial. Prevalensi dari adenoma hipofisis ini masih belum diketahui secara pasti. Studi epidemiologis masih sangat terbatas dan bias oleh faktor eksternal seperti penegakan diagnosis, persebaran penyakit, dan lain-lain menyebabkan terbatasnya data studi epidemiologis, postmortem, dan radiologis. Adenoma hipofisis ini sering kali bersifat asimptomatik atau bergejala tidak khas sehingga diagnosis pun terlambat ditegakkan. Manifestasi adenohipofisis secara klinis ada tiga: sindrom hipersekresi atau defisiensi hormon; manifestasi neurologis akibat efek massa yang membesar dengan modalitas pencitraan. Presentasi kasus: Seorang laki-laki berumur 49 tahun dirujuk ke rumah sakit dengan keluhan sakit kepala kronik dan pandangan kabur. Pemeriksaan fisik secara umum dalam batas normal. Riwayat penyakit sebelumnya atau pengobatan juga tidak spesifik. MRI otak menunjukkan lesi hiperintens pada area suprasellar/sellar. Temuan pemeriksaan hormon juga menunjukkan hipokortisolisme dan hiperprolaktinemia. Kesimpulan: Perawatan konservatif dilakukan dengan subsitusi kekurangan hormon.
\end{abstract}

Kata Kunci: Adenoma pituitari; hiperprolaktism; hipokortisolism

Received 14 October 2020 | Revised 23 November 2020 | Accepted 30 November 2020

\footnotetext{
*Corresponding author at: Department of Internal Medicine, Faculty of Medicine, University of Sumatera Utara, Medan, North Sumatera, Indonesia

E-mail address: amin.fansfn@gmail.com
} 


\section{Introduction}

Pituitary adenomas are the most common type and benign tumors arising from hormone expressing cells in the anterior pituitary gland. They account for $10 \%$ to $15 \%$ of all intracranial masses [1-4]. Pituitary adenomas are broadly categorised as "functioning" (hormone-secreting) and "non-functioning" (non-secreting) adenomas. They can be further classified by cell type and size [1,3,5]. Pituitary adenomas present clinically in three ways: syndromes of hormone hypersecretion or deficiency; neurologic manifestations form the mass effect of an expanding gland; or an incidental finding on imaging done for an unrelated issue [1,3,6]. Pituitary adenomas are often clinically silent or manifest with non-specific symptoms, which can lead to a delayed diagnosis. Clinical practice shows that both functioning and non-functioning pituitary adenomas are likely missed initially due to non-specific symptoms [5].

Pituitary apoplexy occurs in $0.6-10 \%$ of pituitary adenoma, especially non-functioning pituitary adenoma. It evolves in hours to days and is considered potentially fatal emergency occurring in these patients with pituitary adenoma The precise pathophysiology is not completely understood and remains uncertain, could be associated with trauma, iatrogenic, hypertension, systemic surgeries, and dynamic pituitary function test [7-9]. This case presentation demonstrates diagnosis with pituitary apoplexy resulting from pituitary macroadenoma based on clinical manifestation, laboratory assay, radiographic imaging perspectives and conservative management.

\section{Case Illustration}

A 49-years old man, was refered to the H. Adam Malik Public Hospital on October 15th, 2020 with a chief complaint of headache. The patient admitted that he has experienced a headache since 4 months ago and worsened for 1 latest month. Pain is reduced by analgetics use and waxed as if he didn't take medication anymore, it has been getting worse and uncomfortable over days, making it difficult to do daily activities. The patient also complained of blurred vision since 3 months ago, worsened since this last month. It was especially delineated as disturbances in lateral view of the left and right eyes, making it difficult to read small letters in newspapers, no improvement reported by altering reading distance. Weight loss was admitted 1 month ago with approximately $10 \mathrm{~kg}$ accompanied by anorexia. Nausea, vomiting, and swallowing difficulties were absent. Behavior alteration has been recognized since 2 years ago to become more unresponsive to external stimuli, depicted as feeble, more irritable, and anhedonia. Sexual problems were admitted for 2 years. Defecating and urinating were within normal limits. History of fever, shortness of breath, and breast enlargement was denied.

The patient was initially diagnosed with pituitary macroadenoma in September 2020. He has lived with his wife and son. Socioeconomic status was in the lower range, previously worked as a journalist and has not worked for 2 years. There are no similar symptoms experienced by the patient's family. 
The patient appeared to be moderately ill, fully alert, BMI: $27.7 \mathrm{~kg} / \mathrm{m} 2$ (Obese I). BP 120/80 $\mathrm{mmHg}$, pulse rate 90 beats/minute, respiration rate 18 times/minute, temperature $36.7^{\circ} \mathrm{C}$. General physical examination revealed no abnormalities.

Table 1 Clinical Pathology Laboratory Results October $21^{\text {st }} 2020$ (Pre-Treatment)

\begin{tabular}{|c|c|c|c|}
\hline Full Blood Count & Unit & Result & Reference \\
\hline Hemoglobin (HGB) & $\mathrm{g} / \mathrm{dL}$ & 13.2 & $13-18$ \\
\hline Erythrocyte (RBC) & Juta/ $\mu \mathrm{L}$ & 4.23 & $4.50-6.50$ \\
\hline Leukocyte (WBC) & $/ \mu \mathrm{L}$ & 5,760 & $4,000-11,000$ \\
\hline Hematocrit & $\%$ & 38 & $39-54$ \\
\hline Thrombocyte (PLT) & $/ \mu \mathrm{L}$ & 158,000 & $150,000-450,000$ \\
\hline MCV & $\mathrm{fL}$ & 91 & 81-99 \\
\hline $\mathrm{MCH}$ & $\mathrm{pg}$ & 31.2 & $27.0-31.0$ \\
\hline $\mathrm{MCHC}$ & $\mathrm{g} / \mathrm{dL}$ & 34.5 & $31.0-37.0$ \\
\hline RDW & $\%$ & 13.6 & $11.5-14.5$ \\
\hline MPV & $\mathrm{fL}$ & 10.7 & $6.5-9.5$ \\
\hline РCT & $\%$ & 0.170 & $0.100-0.500$ \\
\hline PDW & $\%$ & 11.9 & $10.0-18.0$ \\
\hline LED & $\mathrm{mm} / 1 \mathrm{jam}$ & 10 & $0-10$ \\
\hline \multicolumn{4}{|l|}{ White blood cell count } \\
\hline - Neutrophil & $\%$ & 22.70 & $50.00-70.00$ \\
\hline - Monocyte & $\%$ & 51.20 & $20.00-40.00$ \\
\hline - Eosinophil & $\%$ & 8.90 & $200-800$ \\
\hline $\begin{array}{l}\text { - } \text { Basophil } \\
\text { - Neutrophil Absolut }\end{array}$ & $\%$ & 8.90 & $2.00-8.00$ \\
\hline - Lymphocyte Absolut & $\%$ & 15.50 & $1.00-3.00$ \\
\hline $\begin{array}{ll}\text { - } & \text { Monocyte Absolut } \\
\text { Eosinophil Absolut }\end{array}$ & $\%$ & 1.70 & $0.00-1.00$ \\
\hline \multirow[t]{5}{*}{ - Basophil Absolut } & $10^{3} / \mu \mathrm{L}$ & 1.31 & $2.7-6.5$ \\
\hline & $10^{3} / \mu \mathrm{L}$ & 2.95 & $1.5-3.7$ \\
\hline & $10^{3} / \mu \mathrm{L}$ & 0.51 & $0.2-0.4$ \\
\hline & $10^{3} / \mu \mathrm{L}$ & 0.89 & $0-0.10$ \\
\hline & $10^{3} / \mu \mathrm{L}$ & 0.10 & $0-0.1$ \\
\hline
\end{tabular}

\section{Clinical Chemistry}

\section{Liver Function}




\section{$\mathrm{U} / \mathrm{L}$}

89

0-55

Carbohydrate Metabolism

- Random Blood Glucose

$\mathrm{mg} / \mathrm{dL}$

102

$<200$

Renal Function

- Blood Urea Nitrogen (BUN)

$\mathrm{mg} / \mathrm{dL}$

9

9-21

$\mathrm{mg} / \mathrm{dL}$

19

19-44

$\mathrm{mg} / \mathrm{dL}$

0.75

$0.7-1.3$

\section{Electrolyte}

- Natrium (Na)

- Potassium (K)

- Chloride (Cl)

$\begin{array}{lll}\mathrm{mEq} / \mathrm{L} & 140 & 135-155 \\ \mathrm{mEq} / \mathrm{L} & 3.7 & 3.6-5.5 \\ \mathrm{mEq} / \mathrm{L} & 107 & 96-106\end{array}$

Immunoserology

- $\mathrm{LH}$

$\mathrm{mlU} / \mathrm{mL}$

0.71

Table 2 Clinical Pathology Laboratory Results (Before Therapy)

\begin{tabular}{lccc}
\hline \multicolumn{1}{c}{ Hormone Assay } & Unit & Result & Reference \\
\hline Cortisol & $\mu \mathrm{g} / \mathrm{dL}$ & 1.3 & $3.7-19.4$ \\
Prolactin & $\mathrm{ng} / \mathrm{mL}$ & 53.43 & $2.58-18.12$ \\
TSH & $\mu \mathrm{lU} / \mathrm{mL}$ & 0.76 & $0.35-4.94$ \\
FreeT4 & $\mathrm{ng} / \mathrm{dL}$ & 0.68 & $0.7-1.48$ \\
\hline
\end{tabular}

On November $4^{\text {th }} 2020$, hormone assay was re-monitored with the following results.

Table 3 Results of Clinical Pathology Laboratory November $4^{\text {th }}, 2020$

(Post Euthyrax 1x50mcg and Prednisone 10-0-5mg Treatment)

\begin{tabular}{lccc}
\hline \multicolumn{1}{c}{ Hormone Assay } & Unit & Outcome & Reference \\
\hline Cortisol & $\mu \mathrm{g} / \mathrm{dL}$ & 5.1 & $3.7-19.4$ \\
Prolactin & $\mathrm{ng} / \mathrm{mL}$ & 48.13 & $2.58-18.12$ \\
$\mathrm{TSH}$ & $\mu \mathrm{IU} / \mathrm{mL}$ & 0.93 & $0.35-4.94$ \\
FreeT4 & $\mathrm{ng} / \mathrm{dL}$ & 0.86 & $0.7-1.48$ \\
\hline
\end{tabular}

On September 14th 2020, MRI brain T1W scan revealed hyperintense lesions in the sella/suprasellar area, dimension $\pm 3.3 \times 2.9 \times 2.5 \mathrm{~cm}$ with a fluid-fluid level (snowman shape), pressing optic chiasm superiorly. T2W and FLAIR appeared hyperintense. There were also hyperintensity lesion in the left and right periventricular areas of white matter. At T2 GRE, the 
susceptibility effect appeared on the dependent part of the sella/suprasellar lesion. No mass effect and midline shift. Cortical sulci and ventricular system were normal. Normal brain stem signals appeared. Normal left and right IAC. There was no abnormal enhancement of the lesion in the sella/suprasellar region. The right and left cavernous sinuses are normal.

Patient was diagnosed with putuitary macroadenoma suspect apoplexy with secondary hypothyroid, hypocortisolism, and hyperprolactinemia. Differential diagnosis includes pituitary macroadenoma suspect apoplexy due to craniopharyngioma or metastatic tumor, tersier hypothyroid, and prolactinoma.

\section{Discussion}

Pituitary adenomas are the most common type and benign tumours arising from hormone expressing cells in the anterior pituitary gland. They account for $10 \%$ to $15 \%$ of all intracranial masses $[1,2,3,4]$. No epidemiologic data found to delineate prevalence-incidence of pituitary adenoma in Indonesia. Yet, study from University of Indonesia estimates incidence of pituitary adenomas accounts at approximately 2:100.000 lives $(0.2 \%)[10,11]$.

Pituitary adenomas are broadly categorised as "functioning" (hormone secreting) and "nonfunctioning" (non-secreting) adenomas. They can be further classified by cell type and size. Functional adenomas are more common and tend to present earlier, in younger patients, with symptoms or signs of hormone excess (eg, hyperprolactinaemia). In contrast, non-functioning adenomas are clinically silent until the lesion has become large enough (usually $>1 \mathrm{~cm}$ ) to have mass effect $[1,3,5]$. Prolactinomas comprise $40 \%$ to $57 \%$ of all adenomas, followed by nonfunctioning adenomas ( $28 \%$ to $37 \%$ ), hormone-secreting adenomas (11\% to $13 \%$ ), and adrenocorticotropic hormone (ACTH) secreting adenomas (1\% to $2 \%)$. Tumors are also categorized based on size. If the tumor is $10 \mathrm{~mm}$ or larger, it is considered a macroadenoma; if it is less than $10 \mathrm{~mm}$, it considered a microadenoma. Microadenomas are slightly more common than macroadenomas $(57.4 \%$ vs. $42.6 \%)$ [1,3,4]. Also, considered a giant adenomas if size exceeds $40 \mathrm{~mm}[12]$.

Pituitary adenomas present clinically in three ways: syndromes of hormone hypersecretion or deficiency; neurologic manifestations from mass effect of an expanding gland; or an incidental finding on imaging done for an unrelated issue $[1,3,6]$. Headaches are common in pituitary adenomas (37-70\%) but are usually non-specific and often not the predominant presenting feature, unless in association with acromegaly or pituitary apoplexy. Headaches, which are believed to result from stretching of the dural sheath, are nonspecific and do not necessarily correlate with tumor size $[3,10]$. In pituitary apoplexy, headache is sudden, severe, and often associated with visual disturbance or ocular palsy. It occurs when there is acute hemorrhage or infarction within pituitary adenomas (2-12\%) and can be life threatening if not treated promptly. [5] Pituitary 
apoplexy can occur in pituitary tumors due to intratumoral hemorrhage or infarction. Risk factors for apoplexy include anticoagulant drugs, hormone stimulation testing, intracranial surgery, or dopamine agonists. However, the pathogenesis of pituitary apoplexy is largely unknown.[13]

Neurologic symptoms are more common in non-functioning adenomas or gonadotroph adenomas because these tumors do not secrete sufficient hormones to cause endocrine-type symptoms, and their diagnosis often is delayed until presented with mass effect: the visual field defect usually goes unnoticed by the patient until severe and is typically a bitemporal hemianopia due to chiasmatic compression. If the adenoma expands laterally into the cavernous sinus, it has the potential to affect the cranial nerves housed there, including cranial nerves III (oculomotor), IV (trochlear), and VI (abducens). In contrast with headaches, visual disturbances tend to correlate with tumor size, tend to occur insidiously so that many patients are not aware of them until they are specifically tested. $[1,3,6,14]$

Pituitary adenomas are often clinically silent or manifest with non-specific symptoms, which can lead to a delayed diagnosis. Clinical practice shows that both functioning and non-functioning pituitary adenomas are likely missed initially due to non-specific symptoms such as, tiredness, weight gain, problems with periods, libido, and erectile dysfunction. Underlying endocrine problems are a relatively rare cause of such symptoms in primary care, therefore the relevant initial examinations for pituitary adenoma (visual fields and blood tests) may not be considered. [5]

A patient who presents with symptoms of hormone excess likely has a functioning adenoma. Evaluation can be geared toward the specific hypersecretory syndrome. Hormone deficiencies should also be evaluated because hypopituitarism is present in up to $30 \%$ of adenomas, and because of the need to address deficiencies in future treatment regimens. Consensus guidelines recommend obtaining an endocrine panel as an initial set of laboratory tests. This includes serum prolactin, insulin-like growth factor 1 (IGF-1), LH/FSH, TSH, thyroxine (T4), and an initial test for cortisol excess-a 24-hour urine free cortisol, a late night salivary cortisol, or a low-dose dexamethasone suppression test. The 24-hour urine free cortisol, late night salivary cortisol, and overnight dexamethasone suppression tests have similar accuracy (positive likelihood ratio [LR+] $=10.6$, negative likelihood ratio $[\mathrm{LR}-]=-0.16 ; \mathrm{LR}+=8.8, \mathrm{LR}-=0.07$; and $\mathrm{LR}+=16.4, \mathrm{LR}-=$ 0.06 , respectively). Dexamethasone suppression and 24-hour urine free cortisol tests have the highest specificity (97\% and 91\%, respectively) and the most evidence to support their use. When the diagnosis remains uncertain after these initial studies, dynamic endocrine function tests should be performed, usually in consultation with an endocrinologist. [3]

A higher serum prolactin level $(250 \mu \mathrm{g}$ per L [10.870 pmol per L] or more) suggests a prolactinoma over other causes of hyperprolactinemia (e.g. hypothyroidism, medications, nonprolactin-secreting pituitary adenomas, pregnancy, renal failure). A serum prolactin level greater 
than $500 \mu \mathrm{g}$ per L (21.739 pmol per L) is diagnostic for a macroprolactinoma ( $98 \%$ specificity), although only about one-third of persons with prolactinoma have levels that high $(35 \%$ sensitivity). Non-prolactin-secreting pituitary tumors may cause moderate elevations in prolactin through compression of the pituitary stalk, resulting in loss of inhibition of prolactin release; this is termed the stalk effect $[4,11,12]$. If the tumor is very large $(>3 \mathrm{~cm})$, the very high prolactin levels (usually $>10000 \mu \mathrm{g} / \mathrm{L}$ ) may rarely saturate the antibodies in some assays, leading to artifactually low or normal results (the "hook effect") and prolactin levels should be rerun at 1:100 dilution to exclude this.[12]

Rapid pituitary adenoma growth causes a sudden increase in intrasellar pressure which results in ischemic necrosis of various portions of the anterior pituitary gland and further damage of normal residual tissue, limiting the chances of hormone function recovery. ACTH deficiency reported in $70 \%$ of cases, is the most important hormone deficiency. TSH and gonadotropin deficiency have also been reported in $50 \%$ and $75 \%$ of cases, respectively, but they generally become clinically relevant only after several months when directly caused by pituitary necrosis $[7,8,9,15]$. It leads to low production of cortisol and thyrosine, as shown in this case. Furthermore, mineralocorticoid levels are normal in ACTH-deficient patients. Hyponatremia is a direct consequence of glucocorticoid deficiency, and is related to inappropriate antidiuretics resulting from nonsuppressible arginin vaspressin release and, probably, to a direct renal water excretion defect, both being consequences of cortisol deficiency. [8,9,15]

Increased use and sensitivity of computed tomography (CT) and magnetic resonance imaging (MRI) have identified many pituitary lesions that otherwise might not have been detected. Autopsy and radiology studies suggest that between $5 \%$ and $20 \%$ of all pituitary adenomas may be unsuspected or found incidentally.[1,6,10,16] If a pituitary mass is suspected, MRI is the best initial imaging study. MRI is $61 \%$ to $72 \%$ sensitive and $88 \%$ to $90 \%$ specific for sellar masses. The study should be done with and without gadolinium enhancement. CT is limited by its inability to precisely image the optic chiasm. If an MRI is contraindicated or unavailable, CT done with thin sections ( $1.5 \mathrm{~mm}$ or less) and in a coronal plane will improve imaging of the pituitary region. There are three primary treatment goals for pituitary adenomas: reducing hormone hypersecretion and its clinical manifestations; decreasing tumor size to improve symptoms of mass effect; and correcting hormone deficiencies. [3]

MRI is the imaging test of choice for diagnosis because it detects $90 \%$ of the cases (CT scan detetcts $20 \%$ only).[7] As hyperdensity in the subacute and chronic phases of hemorrhage fades, CT sensitivity to diagnose PA diminishes and the lesion could be misdiagnosed as an abscess or cystic degeneration. In contrast, $\mathrm{CT}$ is superior during the first three hours after apoplexy. Usually in the first week, an isointensity on T1-weighted scans and a hypointensity on T2-weighted images can be observed with MRI. Subacutely, there is focal or heterogeneous increased signal on T1-weighted scans, and a progressive increase in signal on T2-weighted images. In the chronic 
phase, there is signal increase in both $\mathrm{T} 1$ and $\mathrm{T} 2$ weighted images. Necrosis imaging can be detected as hypodensity by CT and hypointense on T1 and hyperintense on T2 on MRI. [9]

Nonfunctioning pituitary macroadenoma treatment can involve single or combinations of surgical intervention, radiotherapy or pharmacological treatment. For those adenomas larger than $1 \mathrm{~cm}$ (the majority), after excluding hormone deficiencies, it is common to proceed to surgical management. Pharmacological treatment of the Nonfunctioning pituitary macroadenoma itself is typically unsuccessful. Medical management is frequently based around regular follow-up, monitoring of visual problems, and secondary hormone deficiencies .[17] The patients require hydrocortisone replacement, an adrenal crisis (acute cortisol insufficiency) can ensue during times of illness which can be life-threatening and must be managed.

As regards treatment due to hypocortisolism, this patient in this case received prednisone 10-0-5 $\mathrm{mg}$. In fact, glucocorticoid replacement therapy is the most effective medical intervention because secondary adrenal insufficiency is the most significant risk factor for death and complication. The use of hydrocortisone 100-200 mg IV, followed by a continuous IV infusion of 2-4 mg per houris recommended. The use of dexamethasone is not recommended; however, it could be useful in decreasing edema as a nonsurgical approach to pituitary apoplexy. [7, 8,9,15] Because acute secondary adrenal insufficiency is very frequent in patients with apoplexy, empiric parenteral corticosteroid supplementation should be given to all patients with signs of pituitary apoplexy, without waiting for diagnostic confirmation [15]. Overall, patients suffering from pituitary apoplexy will require glucocorticoids (60-80\%), thyroid hormone (50-60\%), and desmopressin $(10-25 \%) .[7,15]$

Therefore, it is advised that MRI should be repeated annually in these patients. The operation or radiotherapy should be contemplated only when the tumor regrowth is confirmed, except where the adenomatous residue is tebal dan dekat to the optic nerves/chiasm.[18] Whether Nonfunctioning pituitary macroadenoma are associated with an increased mortality or reduced lifespan is still unknown.[19]

\section{Conclusion}

We have reported a case of newly diagnosed patient with nonfunctioning pituitary macroadenoma. Medical management is frequently based around regular follow-up, monitoring of visual problems and secondary hormone deficiencies. The patients require hydrocortisone, thyroid hormone replacement, monitoring of visual problems.

\section{REFERENCES}

[1] Hidayat, Muhammad, “Adenoma Hipofisis,” Tinjauan Pustaka Jurnal FK Unand, vol. 38, Nomor 2, Agustus 2015. 
[2] H. Elizabeth, G. Wira, "Manifestasi Disfungsi Beberapa Hormon dari Seorang Penderita dengan Riwayat Adenoma Hipofisis," Laporan Kasus J Peny Dalam, vol. 8 no.1, Januari 2007.

[3] L. Marcy, K. Linda, C. Samya. "Pituitary Adenomas: An Overview," American Family Physician Website. 2013. http://www.aafp.org/afp/2013/0901/p319-s1.html.

[4] A. Khalid, B. Samia, A. Faisal, A. Muneera, K. Patan, "The epideniology of pituitary adenomas in a community-based hospital: a retrospective single center study in Saudi Arabia," Ann Saudi Med, 36(5): 341-5. September 2016, doi: 10.5144/0256-4947. 2016.

[5] P. Aparna, L. Laurence, W. John, "Pituitary Adenomas," BMJ, June 2019. doi: 10.1136/bmj.I2091

[6] M. Moises, M. Virgilio, S. Latife, C. Dalia, "Clinically non-functioning pituitary adenomas: Pathogenic, diagnostic and therapeutic aspects," Endocrinologia, Diabetes y Nutricion, Elsevier, July 2017. http://dx.doi.org/10.1016/j.endinu.2017.05.009

[7] Pinto-Valdivia M, et al. Apoplejía pituitaria. A propósito de un caso. Endocrinol Nutr 60:37-47. 2013

[8] Albant A, ferrati F, Angileri FF, Esposito F, Granata F, et al. Multidisciplinary management of pituitary apoplexy. Int $\mathrm{J}$ Endrocrinol.;1-11.2016 http://dx.doi.org/10.1155/2016/7951536

[9] Glezer A, Branstein MD. Pituitary apoplexy: pathophysiology, diagnosis and management. Arch Endocrinol Metab 59(3):259-65. 2015. DOI: 10.1590/2359-3997000000047

[10] C. Rahmat, S. Pradana, D. Budiman. "Gambaran Klinis dan Proporsi Hipotiroidisme Sekunder pada Pasien Adenoma Hipofisis di Rumah Sakit Cipto Mangunkusumo," Artikel Penelitian J Indon Med Assoc 68(6), Juni 2018.

[11] G. Ni Putu, H. Hanik, "Laporan Kasus: Perbaikan Kadar Prolaktin pada Makroadenoma Hipofisis dengan Terapi Bromokriptin dan EETA,” Jurnal Farmasi Klinik Indonesia, 9(3) hal. 237-44. 2020

[12] M. Mark, "Diagnosis and Treatment of Pituitary Adenomas A Review," Clinical Review \& Education, JAMA Review, vol. 317, no.5. February 2017. DOI: $10.1001 /$ jama.2016.19699

[13] Melmed ,Shlomo, "Pituitary Tumors," HHS Public Access, Author Manuscript, vol.44, no. 1, p:1-9, March 2016, doi: 10.1016/j.ecl.2014.11.004.

[14] Herse, Peter. "Pituitary macroadenoma: a case report and review," Clinical and experimental Optometry, vol. 97, p:125-132, May 2013. DOI:10.1111/cxo.12099

[15] Briet C, Salenave S, Bonneville JF, Laws ER, Chanson P. Pituitary Apoplexy. Endocr Rev vol. 36, no.6, p:622-45. 2015. doi: 10.1210/er.2015-1042

[16] M. Bradley, W. Robert, C. Ryan, "Demographic Differences in Incidence for Pituitary Adenoma," NIH Public Access, vol. 14, no.1, p:23-30, March 2011. doi:10.1007/s11102010-0253-4.

[17] Saunders S, Vora JP. Endocrine evaluation of pituitary tumours. Br J Neurosurg vol.22, no.4, p:602-8. 2008

[18] Chen Y, Wang CD, Su ZP, Chen YX, Cai L, Zhuge QC, Wu ZB. Natural history of postoperative nonfunctioning pituitary adenomas: a systematic review and meta-analysis. Neuroendocrinology vol.96, p:333-42. 2012

[19] Ellegala DB, Alden TD, Couture DE, Vance ML, Maartens NF, Laws Jr ER. Anemia, testosterone, and pituitary adenoma in men. J Neurosurg vol.98, no.5, p:974-7. 2003 